\title{
FEMALE NETWORKS
}

\section{Collecting contacts with Gabrielle Enthoven}

\author{
Kate Dorney
}

In her Times obituary Gabrielle Enthoven (née Romaine) ${ }^{1}$ (1868-1950) was described as an 'archivist of the theatre' and an amateur actor who had 'some success as a dramatic author'. ${ }^{2}$ For Who's Who in the Theatre she described herself as a

theatre historian and dramatic author [...] for many years a prominent amateur actress appearing with the Old Stagers, Windsor Strollers etc. and author of Montmartre, Alhambra 1912; Ellen Young (with Edmund Goulding), Savoy 1916; The Honeysuckle (from D'Annunzio's play), Lyceum, New York in 1921. (Parker, 1930: 318-19)

More colloquially, she was described as 'the theatrical encyclopedia' initially a one-woman, one-stop shop for information on the where, when and how of theatre; by the time she died, the instigator and overseer of the Victoria and Albert Museum's (V\&A) theatre collection. ${ }^{3}$ Persuading the museum to accept the collection was no easy task, despite Enthoven's social and professional connections to a range of influential figures, and this chapter examines the ways in which she used her connections to further her work as a practitioner, collector and spokesperson and what this can tell us about women's influence in the theatrical sphere and in public life. It also reflects further on my motivation for excavating Enthoven from the obscurity she apparently sought.

As I have discussed elsewhere, despite, or perhaps because of, her evident talents as a preserver of theatre history and as a worker for the British Red Cross's missing persons units in the First and Second World Wars, Gabrielle Enthoven is an elusive biographical subject (Dorney, 2014a; 2014b). She appears in passing in biographies and autobiographies of other, more famous people, notably Ellen Terry, Oscar Wilde, Noël 
Coward, Edmund Goulding, Radclyffe Hall and Lillah McCarthy, but these reveal little about her. Shortly after Enthoven's death, Muriel St Clare Byrne wrote a short tribute for Theatre Notebook, the journal of the recently formed Society for Theatre Research. ${ }^{4}$ She noted

her important Red Cross records work during both wars was described
in The Times's notice of her death, which also mentioned her work as a
dramatic author. It is to be hoped that presently someone more nearly
of her own generation may give us a more personal sketch, telling us,
perhaps, of the young amateur actress who was coached by Henry Irving
for her part in Twelfth Night only to find her carefully rehearsed render-
ing of a crucial passage disapproved of by her producer, William Poel
[...] She was a born raconteuse and would keep any company enthralled
by her theatre reminiscences, but glimpses of herself were all too rare.
(Byrne, 1950: 2-3)

St Clare Byrne hoped in vain: such a personal sketch never appeared. Enthoven's museum colleagues James Laver and George Nash both provided reminiscences of her that reproduced many of her favourite anecdotes, but few personal details (Laver, 1952; Nash, 1956). Michael Holroyd once considered writing a biography of her, but early on in his research at the V\&A he was drawn to a Rodin bust of Eve Fairfax and ended up writing about her instead (Holroyd, 2004: 62). He called it The Book of Secrets, which would have been an equally appropriate name for a book on Enthoven, who so effectively covered the traces of her own personal life. Even the 'facts' that the theatrical encyclopaedia provided for her Who's Who in the Theatre entry are difficult to verify. She is not listed in the Windsor Strollers or Old Stagers membership records and she seems to have appeared with them only once. ${ }^{5}$ She did work for the Red Cross, but never seems to have discussed how she came to work there or what she did. The vignettes and passing mentions in biographies and autobiographies add little flesh to the bare bones: she certainly knew Noël Coward and Radclyffe Hall, although it's hard to work out how well.

Fleshing her out has become an exercise in mirroring her own practice of collecting, compiling and verifying 'facts' and anecdotes from newspapers and from the collection she initiated and others, now housed in the V\&A and elsewhere: ${ }^{6}$ an exercise in sifting through accumulated layers of documents, reports and footnotes of work on other more famous figures in order to build a fuller picture of her life and work, for information that will corroborate (or not) the anecdotes that circulated 


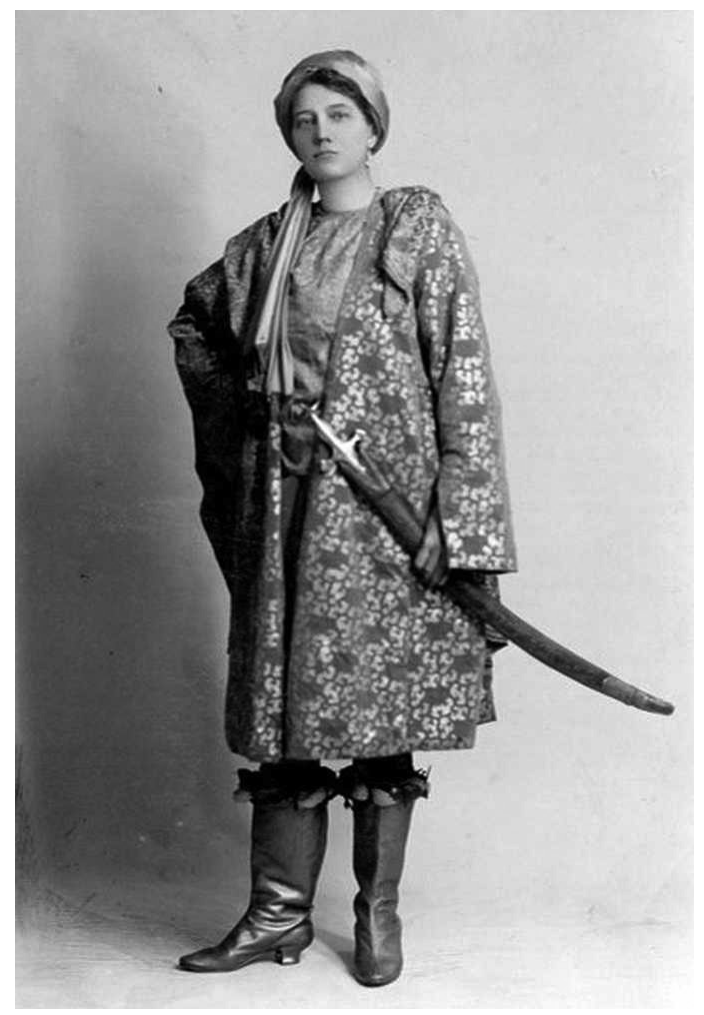

3 Gabrielle Enthoven in fancy dress, date unknown.

from her 'inexhaustible fund of stories about personalities' ranging from Queen Victoria and General Gordon, to Sarah Bernhardt, Noël Coward and Mrs Patrick Campbell (Laver, 1952: 8). Her 'personal' collection in the V\&A consists of a small number of boxes of scrapbooks, letters, photographs and notebooks that contain little personal information. ${ }^{7}$ Letters to and from her in the archives of her wider circle of acquaintance are often either short and business-like, or long and revealing about the writer, but not the receiver. Reading some of the letters, I often suspected that she wrote them only in order to receive a response which she could file and so increase her collection, the growth, organisation and custodianship of which obsessed her.

Like the collection, the version of herself that Enthoven bequeathed to posterity was carefully arranged. Her will instructs that her solicitor, 
to the exclusion of all other persons whatsoever shall go through the whole of my papers and deal with the same as to him, in his uncontrolled discretion shall seem best [...] and to see that all Paper matters and things relating to Theatre go to my collection at the Victoria and Albert Museum. ${ }^{8}$

'Uncontrolled discretion' suggests scandal, but is actually a legal term allowing trustees to act without prior permission from the court. The 'personal papers' at the museum contain no information about her parents, her brother or her husband other than photographs of them. They do contain a short history of the Romaine family and a history of her childhood home, but nothing about her education, her involvement in amateur theatricals or the Red Cross other than her certificate of membership, badges, OBE and photographs. The chief source of information about her is anecdotes she related in interviews, which are then, in turn, related by others in remembrances and obituaries. What I have learned has come from those interviews, public records, reviews and the few personal letters that, for reasons unknown, escaped the solicitor's discretion. She had seen at first-hand how compromising letters could be, through the trial of Wilde and through the public disagreement of her friends Edith Craig and Edward Gordon Craig over how their mother, Ellen Terry, should be remembered. As well as establishing a museum at Smallhythe dedicated to Terry's memory, Craig placed an announcement in the national press asking for letters written by her mother to be returned to her for publication. According to Katharine Cockin, the subsequent publication, including letters from George Bernard Shaw, was regarded by Gordon Craig as 'as an act of indecent exposure, misrepresentation and betrayal' and he retaliated by publishing Ellen Terry and her Secret Self (1932) in which he 'claims for himself the authorised portrait of his mother, privileged access to her "secret self" not available to his sister' (Cockin, 2010: $\mathrm{xx}$ ). In her introduction to the recently published volumes of Terry's correspondence, Cockin notes that the 'collection has been subjected to censorship in later years by means of selective destruction ... since many of Ellen Terry's letters, especially those to significant male intimates and to others in certain periods of her life, appear to have been destroyed there are gaps in her life story' (Cockin, 2010: xvi-xvii).

In Enthoven's case, there is more gap than story. In her walk-on role in other people's biographies, she is usually described as a lesbian and as part of the London lesbian haut monde of the 1920s. She appears most 
frequently in biographies of Radclyffe Hall, where she is variously identified as being introduced to Hall by Hall's partner Mabel Batten (Cline, 1997: 67, 73-4, 80) or by the tennis player and former ambulance squadron founder Toupie Lowther (Baker, 1985: 134). According to a third biographer, Diana Souhami, Enthoven's relationship with Hall and Una Troubridge foundered because she urged 'discretion and camouflage' in the wake of The Well of Loneliness libel trial of 1928. They criticised her for 'repudiating her own kind when opportune to do so' and Troubridge declared, 'she's a rat and we have no use for her' (Souhami, 2013: 328). Researching Enthoven further through Troubridge's diaries, Eve Smith found further evidence of Troubridge and Hall's belief that Enthoven hid her sexuality. ${ }^{9}$ Given Enthoven's proximity to Wilde and Hall and the vantage point it offered her on the vilification of 'inverts', it is not surprising that she favoured discretion. ${ }^{10}$ Nor is it surprising that there are no letters from Hall or Troubridge among Enthoven's correspondence, nor any other frank discussions of relationships, lesbian or otherwise. As Laura Doan points out in her account of women's experience of work and relationships during the First World War, frankness over such matters is uncommon:

Rumours and accusations of a sexual nature put some of the women in my case studies in the national spotlight, but I found no private papers disclosing their innermost thoughts about their romantic entanglements or their sexual desires, preferences, or inclinations; and during the war and into the interwar period, none ever spoke of themselves or others in reference to modern categories of sexual identity. (Doan, 2013: 5)

Enthoven's sexuality may well account for the absence of many personal documents, and it was never my purpose to 'discover' evidence of it. However, it would have been nice to discover something about her journey from adolescence to adulthood: how she met people like Wilde and Ellen Terry; how she came to the Red Cross; what she thought about the suffrage movement, cinema, or any of the changes and innovations she lived through. ${ }^{11}$ But Enthoven's correspondence reveals little about her personal relationships, health and happiness - although it's clear that she was often unwell, and in old age, unhappy. There are few signs of affection, ease or humour in her dealings with people with whom she is supposed to have been friends, such as Noël Coward - the correspondence I have seen from Coward to Enthoven is polite rather than friendly, yet she left him 'my Chinese statuette of a warrior on a horse' in her will ${ }^{12}$ - or Oscar Wilde - there are no letters from Wilde 
in Enthoven's correspondence. The exception to this are letters from Ellen Terry, Terry's daughter Edith Craig and her partners Christopher St John and Tony Attwood, the actress and dancer Letty Lind, Nancy Price and Charles Maude. ${ }^{13}$ These offer a glimpse of the generous, largerthan-life personality alluded to in Enthoven's obituaries and tributes. The letters kept in the collection are illuminating about how she used her contacts to get advice on her writing, her acting and as a means of expanding and effectively serving her collection. They reveal a network in which the public and private, the professional and personal, the petitioner and the patron shift in relation to herself, her acquaintances and each other.

Jacky Bratton has shown how women's role in management and business in the West End theatre of the mid-nineteenth century was previously obscured by academic accounts of Victorian business that focused on 'the urgent demands of masculine identity formation' from which women were excluded by social restrictions on where they could go and who they could visit (Bratton, 2011: 105). She also points to the fact that the 'theatrical/Bohemian public sphere' continued to rely on patronesses, and that the 'gatherings they facilitated were still important in the artistic world, after the patronage culture had ostensibly given way to market relations, and it is in accounts of the salon that theatrical women can most easily be seen' (Bratton, 2011: 107). Born in 1868, Enthoven benefited from the social changes that saw women of her class move beyond the salon. She was raised in a tradition of privilege and public service: her father, William Govett Romaine (1815-93), was a colonial administrator and highly valued public servant who served Lord Raglan in the Crimean War, earning the soubriquet 'the eye of the army' (Williams, 2004: n.p.). He then served in India before becoming Advocate General in Egypt. Her mother, Frances Tennant, was the daughter of Henry Tennant, a lawyer, and Elizabeth Roupell, daughter of a Master in Chancery. Enthoven was born in Spring Gardens in London, a street that borders both the West End theatres she chronicled so obsessively and the government ministries that her father represented during his various postings. She and her mother travelled with him, and she claims that by the age of three she could speak several languages, but that she didn't learn to read until she was eleven when the family returned to England on her father's retirement (Nash, 1956: n.p.). They settled at the Priory in Old Windsor, described in 1826 as 'delightfully situated in full command of most beautiful reach of the River Thames', and enjoying 'convenient offices, a capital large garden with a neat cottage and hot 
house, stabling for six or seven horses, double coach house, farm buildings and about 47 acres of rich land'. ${ }^{14}$

The photographic albums, commonplace books and one diary of Enthoven's in the V\&A suggest that her adolescence was typical of her class and era: a life of regattas, amateur theatricals, balls and dinner parties. It was a period in which the proportion of actresses increased and women occupied important roles on stage and behind the scenes as managers, writers and patrons as well as performers. ${ }^{15}$ She met Oscar Wilde as a young woman and in 1889 he dedicated 'Remorse (a study)' to her 'in exchange for an autograph sonnet of Paul Verlaine' (Fong, 1979: 13). ${ }^{16}$ This is the first evidence we have of Enthoven as a collector, trading one piece of desirable memorabilia for another. Sometime between 1890 and 1893 she had a limited edition of stories told to her by Wilde privately printed under the title Echoes. Enthoven sent a copy to the British Museum's Library (now the British Library), ensuring that at least one copy remained in public hands. ${ }^{17}$ Her photo albums show her mingling with soldiers from the nearby garrison and newspaper reports confirm that she attended performances of the amateur theatre company, the Windsor Strollers, at the Theatre Royal in Windsor with her mother.

Enthoven's father died in May 1893, and in December that year she married Captain Charles Henfrey Enthoven of the Royal Engineers at St George's, Hanover Square, London: a smart, fashionable church. Sometime after their marriage the Enthovens moved from Windsor to Cadogan Gardens, a fashionable and wealthy area of London. They also spent time in Chatham, Kent, the regimental headquarters of the Royal Engineers. According to George Nash, her successor at the V\&A:

When Mrs Enthoven came to London as a young bride at the end of the last century, she began to mix with the same sort of people she had known at Windsor. With the newly found respectability of the Theatre it was possible for her - a woman whose personality was always on the grand size - to count among her friends such lions of the theatrical world as Sir Beerbohm Tree, Sir George Alexander and Forbes Robertson, Ellen Terry, Sarah Bernhardt and Eleanor [sic] Duse [...] Also numbered among Mrs Enthoven's friends were several important writers - she knew Oscar Wilde very well and bitterly condemned George Alexander and others for their treatment of Wilde. (Nash, 1956: n.p.)

'The newfound respectability of the Theatre' that Nash alludes to here was signalled by the knighthood given to Henry Irving in 1895, which, 
as Tracy C. Davis suggests, provided performers with 'public acknowledgment of their long struggle for recognition as respectable, responsible citizens on a par with what the census designated as "Class A" professionals - barristers, physicians, the military and the clergy' (Davis, 1991: 4). Irving's knighthood was not the only indication of the relaxation of social hierarchy. Christopher Kent notes that 'the years 1884 to 1914 saw nineteen marriages between actresses and members of the English nobility, 14 of whom were peers' (Kent, 1977: 115).

Now that the theatre was respectable, women of Enthoven's class were able to enlarge their acquaintance and shift roles from patron to petitioner: and in the same period an increasing number of women from 'good' backgrounds appeared on the professional stage. Enthoven seems to have wanted to join them: in 1894 she was presented to the Queen at Buckingham Palace, ${ }^{18}$ and in 1896 she was in correspondence with the actress-manager Sarah Thorne - who ran a School of Acting from the Theatre Royal in Margate - and was asking to attend rehearsals. Her request was refused, but in 1899 she had a small part as Mrs Coleman's maid in a production of The Passport staged at the Theatre Royal Haymarket in aid of the Deptford Fund. The Lady's Pictorial reported that 'Mrs Charles Enthoven, if at moments unduly emphatic, proved completely at home as Markham the censorious'. ${ }^{19}$ By 1901 Enthoven counted opera singer David Bispham, actresses Mrs Patrick Campbell, Letty Lind, Marion Terry and Violet Vanbrugh and actordesigners Edith Craig and Edward Gordon Craig among her friends. She was now firmly established among the newly respectable theatre folk (Alexander and Forbes Robertson) as well as the bohemians (Wilde and the Craigs). Alongside acting, she also had a new hobby: collecting theatre memorabilia:

soon after my marriage [I] began pasting up in scrapbooks various press cuttings dealing with the theatre. The idea of starting a collection of playbills came into my head when I purchased a quantity of them, two hundred I think, from a naval officer which was the foundation of my collection as it stands today. ${ }^{20}$

Collecting gave Enthoven another path into the theatre world that she evidently craved admission to. In this early period it is difficult to get a sense of how much time she spent on collecting and how much on performing. Her correspondence reveals that she performed a whistling solo for Helen Mar in 1900, that Edward Gordon Craig wanted her to play the Virgin Mary for him, and that by 1907 she was renting 
Ellen Terry's country home Smallhythe and inviting her to come to the play she was appearing in at the Peckham Crown Theatre. ${ }^{21}$ It is hard to discern any sense of the conduct of her marriage, and references to Charles are few and far between, until his untimely death in 1910. We might expect a woman who lost her mother and husband in the same twelve-month period to reel somewhat in the aftermath; Enthoven's focus on all things theatrical intensified. In 1911 she began a campaign to establish 'a theatrical section in a national museum', became a founding member of the Pioneer Players alongside Edith Craig, and appeared in Cicely Hamilton's A Pageant of Great Women, produced by Craig for the Actresses' Franchise League (AFL; see Naomi Paxton's chapter in this volume), as 'a graduate' (Enthoven, 1911a: n.p.). Her roles as a theatre collector, 'theatrical encyclopedia' and theatre worker begin to

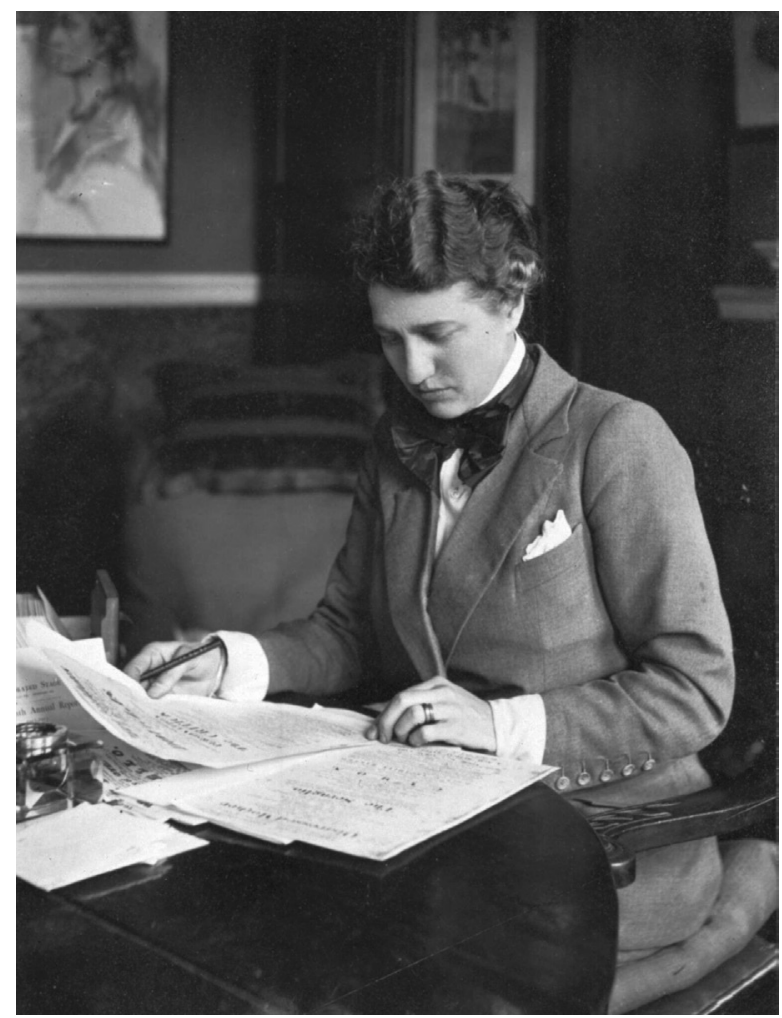

4 Gabrielle Enthoven cataloguing playbills, date unknown. 
merge, and the links made in one domain are exploited in the other. If the producers, actors and writers of her acquaintance cannot help her get parts, or get her plays read or produced (though she continued to ask them until the late 1930s), they can at least support her campaign for a theatre museum and provide material for it. Reading through the correspondence Enthoven saved, there are few extended exchanges with theatre workers that do not make reference to an agreement to send programmes, or provide information. ${ }^{22}$

Enthoven's plays and short stories tend towards the melodramatic, and if she was writing this narrative, her campaign would be precipitated by the death of her husband and mother, which had left her with nothing else to live for. My own more prosaic interpretation is that their deaths meant she was no longer bound by their ideas of decorum, was now independently wealthy, ${ }^{23}$ and benefited from the public appetite for all things theatrical in terms of press coverage of her museum scheme and support for it. ${ }^{24}$ I would further suggest that her peripheral involvement in the suffrage movement and the model it offered for networking and campaigning provided her with both a useful example of practice and an enlarged set of contacts. ${ }^{25}$ The suffrage movement is one example of how associations, clubs and organisations enabled women of Enthoven's age, class and aspiration to network. In Beatrice Harraden's Lady Geraldine's Speech, the suffragist portrait painter Gertrude Silberthwaite ${ }^{26}$ describes how

the Suffrage Movement has brought all us professional women out of our libraries and studios and all our other hiding places. We had to take our share in it, or else be ashamed of ourselves [...] And quite apart from anything to do with the vote itself, it is so splendid coming in intimate contact with a lot of fine women all following different professions or businesses. (Harraden, 2013: 37)

Enthoven is not listed as a member of the AFL, but she was associated with suffrage activities through the Pioneer Players, a subscription society in which members could be both actor and audience. The organisation

was funded by its membership and drew its actors as required from them for each production, honouring them with a reduced fee [...] it was designed to produce only a small number of annual productions for an audience of its membership and was therefore not engaging with the commercial context of public performances for a profit. (Cockin, 2017: 24) 
Enthoven also counted many AFL members and suffragists among her correspondents, including Lena Ashwell, Adeline Bourne, Cicely Hamilton, Gertrude Kingston, Lillah McCarthy, Nancy Price and Irene and Violet Vanbrugh. With them and through them she was involved with a number of charities: the Theatrical Ladies' Guild, the Society of New Players, the Three Arts Club Ball Committee, the Actors' Benevolent Fund and the Stage Society. ${ }^{27}$ They asked her for support, financial and practical; she asked them for introductions, programmes and other items for her collections and advice on getting her work produced. Thus a pattern was established in trading acquaintances, commodities and knowledge.

On at least one occasion it seems that Enthoven was able to use her theatrical heft to assist her friends. Radclyffe Hall's biographer Michael Baker describes her using her influence as member of the Stage Society's council to 'push through' a production of Una Troubridge's translation of Colette's Cheri (1930). There was also an argument over the Baroness's costume which led Troubridge to write in her diary that 'Gabrielle Enthoven behaved disgracefully' (Baker, 1985: 266). The production's poor reviews apparently hastened the end of the Enthoven-TroubridgeHall friendship and did nothing to further any of their theatrical aspirations, but it does show that Enthoven was able to act as patron as well as petitioner (Souhami, 2013: 167).

\section{The campaigner}

In her campaign for a theatre museum, Enthoven worked assiduously to generate publicity. She wrote a number of letters to the press outlining the kind of institution she had in mind, while making personal approaches to a number of museums including the V\&A, the London Museum and the British Museum, and gathering support from the theatre sector. She proposed

a comprehensive theatrical section in an existing museum to comprise specimens of all the different branches necessary to the workings of a play from the construction of the theatre, the designing of the scenery and costumes, to the smallest workings necessary in the house. Also a library and a collection of playbills, prints, pictures and relics etc. I want the section to be the place where the producer, actor, author and critic will naturally go for information, both on what is being done in this and other countries at present, and what has been done before. (Enthoven, 1911a: n.p.) 
In a letter to the Referee she also proposed that

[t]he Copyright Act should be extended to the printing of playbills, to the intent that a copy of the bill of every first performance or revival should be deposited at the museum and duly filed, so as to ensure the keeping of a complete record. (Enthoven, 1911b: n.p.)

She was not simply collecting as a hobby; this was a serious and focused attempt to benefit the theatre profession and theatre scholars.

Her proposals were supported by a number of theatre managers and writers, including George Alexander and Herbert Beerbohm Tree, but were met less enthusiastically by the museum profession. Despite the expansion in museums that took place during her lifetime and the existence of theatre museums and collections in Europe and the US, the idea of theatrical history being documented and studied in a museum context was not a priority for the British establishment. Enthoven offered her collection as a means of creating a national centre and was rebuffed and discouraged for more than a decade. The Keeper of Printed Books at the British Museum thought it 'a very interesting thing', but 'hopeless to think of establishing a theatrical section which should embrace miscellaneous exhibits as theatrical literature here' because of the way the museum was rigidly split into departments. ${ }^{28} \mathrm{He}$ suggested that such a section would be more suitable for the V\&A or the 'London Museum that is in the air'. The V\&A's director Cecil Harcourt Smith described the 'difficulties of our undertaking such a scheme' as 'insuperable. I should have thought that it ought to form naturally part of the proposal for a National Theatre', which was supposed to be being built opposite the museum. ${ }^{29}$

Enthoven, however, continued to collect and to campaign undaunted. For a while it looked as if the London Museum would take the collection once the move to a bigger site had been effected, and Keeper Guy Francis Laking had the difficult task of managing Enthoven's expectations, explaining the lack of space in his existing premises, lack of resources in the new ones and, at one point, trying to dissuade her from selling the collection to America. ${ }^{30}$ Enthoven was in frequent correspondence with American collections and in 1922 spent two weeks working

at Harvard each day for a fortnight and gave two lantern talks on the London stage to some society I forget which - I worked in the Library as they wanted my advice about cataloguing the London ones they had - but at that time they did not mount them - and they were getting very badly handled - and if not mounted I should think they would all be 
destroyed by now. They thought mounting would do away with their value. My point was that they would have no value if they were all in Ribbons - also I thought they made a mistake in separating things so much, as you know I put the playbill, the cuttings, engravings, letter all together, which I think is easier to the student to take in at once. ${ }^{31}$

She stressed the calls on her expertise from other collections as part of establishing the credentials of her collection and herself as its curator.

After more than a decade of petitioning, the V\&A finally agreed in March 1924 to accept her collection of more than 80,000 playbills, prints, books and engravings in order to establish a national collection of the performing arts. The collection was based in the Department of Engravings, Illustrations and Drawings, and Enthoven was allowed a budget of $£ 200$ a year for expenses including postage and packing; everything else, acquisitions, wages and storage, had to be met from her own pocket. After a year of packing, the collection, its founder and workers arrived at the museum and the great task of cataloguing and cadging materials resumed. Enthoven, her volunteers and paid assistants were not only cataloguing the playbills, prints and other material that formed her gift, they were also continuously soliciting contemporary material from venues, managements and performers. Her connections with London's and New York's theatre scene ensured a steady stream of material, enquiries and opportunities for her to enlarge her acquaintance base. The collection enabled her to write to people with whom she wasn't already acquainted, and their replies gave her material for the collection. Until the middle of the 193 os she was also continuing to look for opportunities to write and perform, alongside her curatorial activities.

\section{The theatre 'professional'}

Enthoven's desire to perform seems rarely to have been fulfilled in any public contexts. Aside from the review quoted above of her performance as 'Markham the censorious', other comments on her acting prowess come from the anecdotes related by St Clare Byrne and others - the source of which always seems to have been Enthoven herself. She appears to have set her mind instead on being what she called 'a dramatic author', and her style and choice of subject matter seem to reflect her large personality and taste for the tall story. In 1912 her sketch 'Montmartre' appeared in the long-running revue Kill That Fly! at the Alhambra, described in the Sketch 'as a Grand Guignol playlet': 
The scene is laid in an evil-looking and ill-lighted slum in a Quartier in Paris. Hither stealthily comes an Apache who has successfully brought off a robbery, and brings with him his booty in his bag. But his footsteps are dogged by another of the same kidney, who falls upon him and stabs him. There is a long and fiercely fought combat with knives, which results in the defeat of the original thief who is finally killed. But this does not mean triumph for his assailant, for all the while events have been quietly and closely watched from an open window by a third ruffian, who leaps down upon the exhausted victor and stabs him to the heart, disappearing into the darkness of the night with the 'swag'. ${ }^{32}$

The writer goes on to praise how effective the wordless struggle is and how the grunts of the fight linger and add to the mounting sense of horror. The actors were Charles Maude (also the producer, and married to Enthoven's friend Nancy Price), Victor Maude, Edmund Goulding and 'Mr Hill'. 33

In 1914 Enthoven was working with Cecile Sartoris on a translation of the Italian poet and Fascist politician Gabriele d'Annunzio's play The Honeysuckle. Like Enthoven, Sartoris was a well-connected widow, and like other women of their acquaintance (Romaine Brooks, Elenora Duse, Hall and Troubridge), they seem to have been fascinated by d'Annunzio. ${ }^{34}$ Among Enthoven's papers is a letter to Sartoris from their publisher warning them that 'I cannot anticipate for this play more than a succèss d'estime and I shall be very much surprised if it sold to any extent, so that neither you nor the author must anticipate any substantial return.' ${ }^{35}$ The translation was published in Britain by Heinemann in 1915 and in the US by Frederick A. Stokes and Company in 1916. A generous interpretation might see it as a 'succèss d'estime': the Sketch listed it as one of the best books of the week ${ }^{36}$ but the Times Literary Supplement was rather less complimentary: 'the version before us is written in the tongue best described as translation-English. It would be unfair to select the worst examples, because the whole play (though it improved in the third act) is an example. ${ }^{37}$ It was produced in New York in 1921 and in London in 1937.

Ellen Young, the only other full-length play of Enthoven's to be performed, was co-credited to Edmund Goulding, one of the actors from 'Montmartre'. Produced by the Pioneer Players at the Savoy Theatre in 1916 , the play is a meditation on theatre, the art of living and the role of women. Ellen Young, the heroine of the title, is a young woman from Peckham who works as a typist and whose bluff, working-class parents cannot understand her and her brother's desire for a life beyond seeing 
George Robey at the music hall. On learning that she has tuberculosis and has only a year to live, Ellen accepts an offer from a theatre designer to attend an Arabian Nights ball at Covent Garden and abandons her family: 'I'll go away from here. I will live - for this year.' ${ }^{38}$ In Act 2 she is a highly paid dancer performing as Madame Ziobie, worshipped by fans and visited by admirers who are struck by her 'don't care' attitude. When one of them, Stanley Bretton, accuses her of being unnatural she snaps:

My dear boy, how could I make a living if I was natural? I tried to once - 30 bob a week - being natural - and typing from nine to six; and a hundred pounds a week for letting my voice and legs go at the theatre. The two letters, $\mathrm{U}$ N, which separate the difference between natural and unnatural mean a princely 98 pounds and ten shillings a week to me and to any girl who, either by force of circumstance or natural tendency, becomes hysterical - which is what you really call personality. And then, Stanley, the strength of mind or the strength of circumstances to hold that hysteria with you keep you unnatural. ${ }^{39}$

She later confesses to him that she is dying, but in the nick of time a doctor turns up and says that he can cure her if she will only come and live quietly in his sanatorium.

Act 3 begins with Ellen restored to health, newly 'kind and thoughtful to everyone' and determined to become 'a great artist' by learning her craft. She takes to the stage that evening and it becomes clear to her and her admirers that the hysteria that drove her was the key to her success. After the show she refuses Lord Maperley's offer to keep her as his mistress and is about to shoot herself, but Bretton turns up, again in the nick of time, and challenges her to try a new art, 'the art of living'. She agrees. Curtain.

In 1914 Christopher St John provided a critique of a draft praising the idea, characterisation and dialogue but advising Enthoven to develop theme and pacing, particularly in the final scene in which Ellen struggles between Bretton and Maperley. ${ }^{40}$ St John's letter makes it clear that Enthoven had sent it to her with a view to having it produced by the Pioneer Players, and that she is happy to send it out to the reading committee. She suggests Hilda Moore for the lead role and that Enthoven should invite all the commercial managements along to see it. There is no mention of Goulding's involvement at this stage, so it is possible that Enthoven began it alone and later invited Goulding to co-author with her. Goulding's biographer Matthew Kennedy describes Enthoven as 'a generous, well-read "lady of the world", and Edmund found her the most 
captivating and outsized personality he had ever encountered', not that you would know this from the one letter in Enthoven's papers. Kennedy is rather less enthusiastic about their play.

The plot of Ellen Young serves as a precedent for the many over-heated movie melodramas that would soon consume Edmund's working life. It begins with Ellen predicted to die within a year. She's temperamental and full of fight, and so becomes a wild music-hall dancer. By the final act, a happy marriage has cured her of consumption, morphine addiction, and chronic irritability. 'I wanted to smack the heroine', wrote one first-nighter. 'She was a conceited spitfire of a woman, who was rude to her Peckham parents, but I couldn't help being interested in Hilda Moore's performance.' (Kennedy, 2004: 18)

The production was reasonably well received, with reviewers singling out Hilda Moore's performance as Ellen. A letter from St John in 1916 speaks of an American production being almost 'a fait accompli'; however, it doesn't seem to have come off, nor did a commercial production in Britain. It did, however, become a film, The Quest of Life (1916), directed by Ashley Miller and distributed in the US by Paramount Pictures. It's not clear if Enthoven and Goulding were credited at the time, or paid for their work, though they are now credited on IMDB and in the Library of Congress record for the film.

Although silent on many other subjects, Enthoven's personal papers are revealing about her custodianship of her work and payment for it. Her energetic pursuit of royalties for The Honeysuckle, and her co-writer's credit and royalties for the one-act play The Confederates, written with established playwright and theatre manager H. M. Harwood and performed at the Ambassadors Theatre in 1930, are well documented in her correspondence. ${ }^{41}$ We can interpret this in several ways: first as determination to be paid for her theatrical work and to be able to claim professional status for herself in that regard: authorship is clearly not within the realms of the reciprocal work with her theatrical networks described above. Second, the determination of a wealthy woman not to be taken advantage of, particularly when working in partnership with men. As discussed earlier, at this stage in her life Enthoven was constantly petitioning male directors of museums and libraries to secure her vision for a theatrical section in an institution, and male theatre managers and producers to support her proposal. I like to imagine that she refused to play second fiddle to them in any other sphere of activity, preferring instead to be a version of Lady Bountiful, sending money and 
gifts to Edward Gordon Craig, Edith Craig and others and, on one occasion at least, helping out Noël Coward.

In 1921 Enthoven was in New York for a production of The Honeysuckle at the Lyceum Theatre. She and Cecile Sartoris lived in a small apartment in Washington Square and made space for the young Noël Coward, ${ }^{42}$ then trying to make his name in America. No one had told him that New York theatres closed during the summer months because of the oppressive heat, and he was unable to earn any money, let alone make his fortune. He recalls that the three of them were very poor and often 'dined quietly in pyjamas' (Coward, 2004: 122). Enthoven was never poor, as far as I can make out, although she worried constantly about money (Nash, 1956: n.p.), so it's unclear whether she was pleading poverty at this point, or performing it. ${ }^{43}$ Neither she nor Coward got their lucky break in New York that year, and in fact Enthoven's lucky break as an author never came, despite her describing her work as an author on equal terms with her work as a theatre archivist in Who's Who in the Theatre. The Honeysuckle got a London production at Playroom 6, a small theatre on the first floor of 6 Old Compton Street in 1937. One reviewer commented:

I am not one of the admirers of D'Annunzio the dramatist [...] However, I disliked The Honeysuckle a good deal less than I have disliked other plays I have seen by him, and I thought that not only the makers but also the interpreters of this English version [Hilda Maude, Jean Forbes Robertson, Terence O'Brien] had done their work very well. As I looked round during the interval I caught sight of several people well-known in the world of arts and letters, and I came away feeling that 'Playroom Six' had made a very promising beginning. How far it will go remains to be seen. ${ }^{44}$

Enthoven's dramatic work here, ostensibly the primary focus of the review, has become secondary to her theatrical network in the audience who have turned out to support her. From this point on she seems to have concentrated full-time on collecting, apart from during the Second World War when she returned to the Red Cross.

\section{War worker}

According to her obituary, Enthoven's first role as a war worker was as Chief of Records for the War Refugees Committee 'before the Red Cross claimed her' ${ }^{45}$ Then she became Chief of the Records Department for Central Prisoners of War and Missing Persons (1915-20). As is often the 
case with Enthoven, this is not quite what the official records suggest. According to her British Red Cross record, Enthoven was at the London Office for the Wounded and Missing of the Central Prisoner of War Committee at Carlton House Terrace from December 1915, 'six months before enrolling'. She then became Head of Section in the Records Department between April 1917 and June 1918 before retiring due to illhealth at the age of 50 (British Red Cross, n.d.: n.p.). It should come as no surprise that Enthoven left no written record of her war work, so one can only speculate about her duties based on accounts from other Red Cross workers and from official documents.

In 1921 the government published the 823-page Notes from Reports by the Joint War Committee and the Joint War Finance Committee of the British Red Cross and the Order of St John of Jerusalem in England on Voluntary Aid rendered to the Sick and Wounded at Home and Abroad and to British Prisoners of War 1914-19, which set out the development and eventual standardisation of services provided by the Red Cross and Order of St John. It is clear is that it took time for a centralised system for dealing with prisoners of war and missing persons to be established, and in the earliest period of the war care packages and letters to servicemen were organised regiment by regiment, while enquiries for missing persons were dealt with by the Red Cross. At the suggestion of the War Office, the packing and distribution of parcels, managing of contacts for PoWs and searching for the wounded and missing was centralised. The Central Prisoners of War Committee was established in 1916, bringing together the activities of the Prisoners of War Help Committee (formed in March 1915) alongside the British Prisoners of War Fund, which was 'financially assisted by the Red Cross as well as by private generosity' (HMSO, 1921: 544).

Enthoven is described in the official report as a Superintendent in the Records Department of the Central Prisoners of War Committee. The job of the Records Department was to gather information on PoWs and wounded and missing men on a card index containing name, number, rank, regiment, battalion, company, date and front. They also kept the War Office and next of kin updated on the health and location of PoWs and cross-checked names against lists of those wounded, killed or taken prisoner, received through Frankfurt Red Cross (HMSO, 1921: 533). The Superintendent and her assistant

were responsible for the issue and carrying out of all orders; for the sorting and despatch of incoming post to the various groups; for the 
checking of all outgoing correspondence; for the entry in all the appropriate books of all particulars regarding lists sent out of the department; also for answering any questions and giving any assistance necessary for the efficient maintenance of the work of the department on receipt of information from one of the sources described above, the Superintendent would stamp the date thereon, and place the document in the pigeonhole appropriated to the group of Regiments to which it pertained. If the document contained the names of men belonging to various groups, it was first dealt with by the senior group and then returned to the Super, to be passed on to the next group. (HMSO: 1921, 548)

In the V\&A, Enthoven managed her own collection in much the same way, but whether she went to the Red Cross because she already had these organisational skills, or used what she learned from the Red Cross to organise her collection afterwards, is, like many other things about her, a matter of speculation. The Report of the Joint War Committee of the Red Cross and Order of St John records that it was 'Mrs Barnadistone, who organised the work [of the Records Department] and laid the foundations of the system, carrying it on until Oct 1917', but that to Enthoven's 'organising capacity and devotion to duty, often in the face of bad health, we owe no small part of the success of the work' (HMSO, 1921: 550).

\section{Women and work}

There are parallels to be drawn between Enthoven's work at the Red Cross and her subsequent work in the theatre and at the V\&A, and the work of another Red Cross worker, Velona Pilcher, particularly her play The Searcher, published in 1929. The play is a highly poeticised account of the work of a Red Cross worker at an evacuation hospital whose job it is to update lists of missing and wounded men and send them back to the Red Cross. Pilcher based the play on her experiences as part of the Stanford University Women's Unit of the American Red Cross in an American hospital in France. After the war she became a producer at the Gate Theatre, London, a venue that became renowned for staging experimental and controversial work (Purkis, 2016: 505). The Searcher was produced in Stanford in 1929 and at the Grafton Theatre in London in 1930, and has rarely been performed since. There is no evidence that Pilcher and Enthoven knew each other, but the questions that the Searcher asks in her efforts to trace the missing are not dissimilar to those Enthoven used to organise her own collection, or indeed to the questions I have 
asked of records and archives up and down the country in an effort to track down the missing collector:

\author{
Name of missing man? \\ Number? \\ When last seen? \\ Where last seen? \\ Under what circumstances? \\ Eye-witness? \\ Name of informant? \\ Number? \\ Remarks? (Pilcher, 1929: 4)
}

Like the Searcher, Enthoven's system is predicated on gathering information about persons and events based on the evidence of eyewitnesses and official reports. Like her Red Cross colleagues, she compiled relational indexes of people and places (venues) and titles of works to allow researchers to trace people and works. Unlike her Red Cross colleagues, she worked from first appearance rather than last, underlining the first appearance of an actor, writer, designer or producer in order to create a cross-reference on index cards. She organised the physical material around the information provided on the playbill, filing them by venue in chronological order, supplemented by press cuttings, engravings and any other evidence she could acquire: for example, tally sheets, tokens, letters and designs. Enthoven believed that this made it 'easier for the student to take in at once' ${ }^{46}$ So, for example, the file for the first production of Sheridan's The School for Scandal at Drury Lane in 1777 contains all the bills she was able to collect for the run, along with any newspaper announcements, prints of Sheridan or members of the cast, and any other 'extra' material she was able to collect. Her belief that this made it easier for readers was probably influenced by the popularity of 'Graingerized' or 'extra-illustrated' volumes during her youth. Extra-illustration is the process by in which the owners of printed books unbound them, inserted extra material relevant to the subject, usually prints, photographs and perhaps autographs, mounted on paper or card, and then rebound the whole to create an 'extra-illustrated' edition, sometimes running to multiple volumes. As Robert R. Wark notes:

the words and the pictures are created separately and brought together by a third party who functions neither as a publisher nor a printer but as an interested collector who has the opportunity to create a new artifact out of materials furnished by writers and artists. (Wark, 1993: 152) 
Enthoven found her creative role as such a collector, creating new artefacts out of the materials she acquired through her network of collectors, dealers and theatre workers. As the collection grew, theatre workers came to her for advice and information on historical staging, costuming and on the behaviour of audiences, actresses and everything else. ${ }^{47}$ The collection she began is now the largest of its kind in the world, and renowned among theatre and performance scholars, but, unusually, the person who created it is not: the collection no longer bears her name and many of the elements of it that she acquired are no longer distinguishable because of the way in which she organised the filing system. It is common for collectors to request that the items they have collected remain discrete and/or that the collection bears their name, as with the Mander and Mitchenson Collection now housed at Bristol University, or the collection in the Folger Library in Washington. Enthoven bequeathed her collection to posterity, but obliterated her own story, leaving us with an incomplete context for the establishment and organisation of the collection.

For the duration of my career working with the collection that she founded, I have tried to build a fuller picture to bring context to her collection and to win the same recognition for her as her male contemporaries in theatre and other art forms enjoy. ${ }^{48}$ I resented the lack of attention she had received from theatre scholars and also, historically, from museums and those who wrote about their histories and the histories of collecting. My aim has been to make a place for her in a feminist theatre history by enlarging the connections between the woman and her work 'and the work with the world at large' (Davis, 1989: 66). I had hoped to find more evidence of the spirited raconteur with a fondness for fancy dress hinted at in early interviews, letters and photographs, as well as in the appreciations of those who knew her at the end of her life. But that woman seems to have been too aware of how the judgements of the world at large could impact on a life's work, so what has emerged instead is a picture of a woman who was determined to be judged on her work rather than her life, and who arranged the evidence of her own life as the slimmest of extra-illustrated volumes.

\section{Notes}

1 She is referred to throughout this chapter as Enthoven, even when I am discussing her life before her marriage.

2 'Mrs Gabrielle Enthoven', The Times, 18 August 1950. 
3 She is referred to as 'the theatrical encyclopedia' in a cutting from the Daily Graphic entitled 'Government Theatricals' pasted into an unnumbered scrapbook, Personal Papers of Gabrielle Enthoven, V\&A, THM/114.

4 Enthoven was the first president of the Society for Theatre Research.

5 The Windsor Strollers and Old Stagers archives (U449) are housed at Canterbury Cathedral archives.

6 Archives and collections consulted include the Barry Jackson archive at Birmingham Central Library; the Windsor Strollers and Old Stagers archives at Canterbury Cathedral; the archives of Gwen Ffrangcon Davies and Lillah McCarthy at the V\&A; and the archive of John Gielgud at the British Library.

7 The papers are known as the 'Personal Papers of Gabrielle Enthoven', archive reference $\mathrm{THM} / 114$.

8 Copy of the will of Mrs Augusta Gabrielle Eden Enthoven, Nominal File: Enthoven, Gabrielle Part 2, V\&A.

9 See 'The Private Life of Gabrielle Enthoven', http://www.vam.ac.uk/blog/ theatre-and-performance-2/the-private-life-of-gabrielle-enthoven (accessed 24 August 2018), and Smith (2016).

10 Following Havelock Ellis, Hall described herself as a 'congenital invert' (quoted in Souhami, 2013: 245).

11 Wilde and Terry were friends and both were also friends with Aimee Lowther, as was Enthoven, so it is possible that Enthoven, or Romaine as she was then, met one through the other. The earliest verifiable acquaintance seems to be Wilde, who dedicated 'Remorse' to her in 1889. In 1893 Enthoven's papers show she was staying with Aimee Lowther and by 1902 was in correspondence with Ellen Terry.

12 Copy of the will of Mrs Augusta Gabrielle Eden Enthoven, Nominal File: Enthoven, Gabrielle Part 2, V\&A.

13 Nancy Price provides a pen portrait of Enthoven in her autobiography Into an Hour-Glass (1953), which reproduces many of the familiar facts about Enthoven's relationship with Duse, first-night attendance and fierce dedication to her collection, but also adds a hitherto unreported dimension to her character: 'though not what I would call a religious woman, she had an unassailable faith which many might envy' (Price, 1953: 84).

14 Reading Mercury, 27 March 1826.

15 Census data between 1841 and 1911 shows a steady increase in the number of women reporting as actresses and authors. See Kent (1977) and Davis (1991) for further details.

16 'The poem is written on a card embossed with the address 2 Ryder Street, St James, with the words, 'Written for me by Oscar Wilde in exchange for an autograph sonnet of Paul Verlaine. 10 November, 1889. GE' (Fong, 1979: 13).

17 The stories, and variations on them, subsequently appeared in The Mask, the magazine published by Gordon Craig, and Aimee Lowther was credited 
as the source (see Fitzsimons, 2015: n.p.). They subsequently appeared in Vyvyan Holland's Son of Oscar Wilde (1954).

18 According to Enthoven this wasn't her first encounter with royalty. George Nash recalls that in old age she sometimes reminisced about being invited to Windsor Castle to play with Princess Mary of Teck and of once having slapped the young princess (Nash, 1956: n.p.).

19 Windsor Strollers album 1895-1928, Canterbury Cathedral archives. U499/7/2.

20 Enthoven biographical file, V\&A.

21 The transaction is documented in letters between Terry and Enthoven (Cockin, 2014: 81-3, 84-5, 97).

22 Letters from Arthur Bouchier, Alfred Butt, Harley Granville-Barker, Lewis Casson, Charles Hawtrey, Barry Jackson, Edward Knoblock, Charles Maude, Nigel Playfair, Fred Terry and Herbert Beerbohm Tree all make such an undertaking, as do letters from actors and actresses such as Lilian Braithwaite, Hayden Coffin and Ellen Terry.

23 The probate register shows Charles's estate totalling $£ 2,891$ on his death in 1910 , equivalent to more than $£ 200,000$ today.

24 See Kent (1977: 110-11) for a succinct summary of this.

25 See also Clay (2006) for another example of the elaborated professional/ personal network, in this case, writers for Time and Tide magazine.

26 Silberthwaite goes on to elaborate on her current activities, which include painting all the prominent suffragists including Christabel Pankhurst. Pankhurst was in fact painted by Ethel Wright and the painting was exhibited the same year as the play was produced, 1909. Enthoven was also painted by Wright sometime between 1880 and 1900 and mentions the portrait in her will. Its current whereabouts are unknown. It was last recorded as being sold at Bonhams in 2002, titled 'Lady with the White Carnation'.

27 See Hindson (2016) for a detailed discussion of actresses and theatrical charities in late nineteenth and early twentieth centuries.

28 Farqharsson Sharp, letter to Gabrielle Enthoven, no date, Enthoven scrapbook, V\&A, PN1620.L7.

29 Cecil Harcourt Smith, letter to Gabrielle Enthoven, no date, Enthoven scrapbook, V\&A, PN1620.L7.

30 Guy Francis Laking, letters to Gabrielle Enthoven, Enthoven scrapbook, V\&A, PN1620.L7. The London Museum moved from Kensington Palace to the West End of London in 1914.

31 Gabrielle Enthoven, letter to Constance Kyrle Fletcher, 22 May 1945, Gabrielle Enthoven Collection, V\&A, THM/114/6.

32 'About the Halls', The Sketch, 15 January 1913, p. 60.

33 No first name is given for Mr Hill in the programme.

34 James Laver, Enthoven's friend and colleague at the V\&A, noted that Duse was 'infatuated' with d'Annunzio. 'Sphere of Books', The Sphere, 12 April 1930, p. 82. 
35 Letter to Enthoven, 16 July 1914, Personal Papers of Gabrielle Enthoven, $\mathrm{V} \& \mathrm{~A}, \mathrm{THM} / 114 / 6$.

36 The Sketch, 20 October 1915.

37 Times Literary Supplement, 14 October 1915.

38 Gabrielle Enthoven, unpublished typescript for Ellen Young, p. 16, Personal Papers of Gabrielle Enthoven, V\&A, THM/114.

39 Ibid., p. 12.

40 Christopher St John, letter to Gabrielle Enthoven, 10 July 1914, Gabrielle Enthoven Collection, V\&A, THM/114/6.

41 Personal Papers of Gabrielle Enthoven, V\&A, THM/114.

42 Coward's friend and secretary Cole Lesley describes Enthoven as one of 'four friends' Coward had in New York; the other three were Lord Alington, Teddie Gerard and Cecile Sartoris (Lesley, 1976: 67). His biographer Sheridan Morley describes her as 'a vague acquaintance' (Morley, 1974: 74).

43 Nash refers to her worry about 'living on her capital', but the probate value of her estate was $£ 20,727$ (around $£ 480$, ooo today).

44 H. M. Wallbrook, 'The Honeysuckle', Play Pictorial, June 1937, p. xiii.

45 'Mrs Gabrielle Enthoven', The Times, 18 August 1950.

46 Enthoven to Contance Kyrle Fletcher, 22 May 1946, Personal Papers of Gabrielle Enthoven, V\&A, THM/114/6.

47 During her lifetime Enthoven submitted an annual report to the V\&A outlining her acquisitions and also who had used the collection and for what purpose.

48 As Eve Smith notes, collecting theatrical memorabilia, with the exception of Shakespeareana, has never had the same cultural capital as collecting books, fine and decorative arts, and their collectors are rarely written about or discussed (Smith, 2016). Furthermore, even in fine and decorative art studies, women collectors, as opposed to patrons, are rarely discussed. Charlotte Gere and Marina Vaizey's Great Women Collectors (1999) is a rare exception. Enthoven now has an entry in the Oxford Dictionary of National Biography because I was invited to contribute an entry on a subsequent curator of the collection, and pointed out that it seemed odd for the founder of the collection not to be included.

\section{References}

Baker, Michael (1985), Our Three Selves: The Life of Radclyffe Hall, London: Hamish Hamilton.

Bratton, Jacky (2011), The Making of the West End Stage: Marriage, Management and the Mapping of Gender in London, 1830-1870, Cambridge: Cambridge University Press.

British Red Cross (n.d.), 'First World War Volunteers', http://www.red 
cross.org.uk/en/About-us/Who-we-are/History-and-origin/First-World-War (accessed 24 August 2018).

Byrne, Muriel St Clare (1950), 'Gabrielle Enthoven O.B.E', Theatre Notebook, 5, pp. $1-3$.

Clay, Catherine (2006), British Women Writers 1914-1945: Professional Work and Friendship, Aldershot: Ashgate.

Cline, Sally (1997), Radclyffe Hall: A Woman Called John, London: John Murray.

Cockin, Katharine (2010), 'General Introduction', in The Collected Letters of Ellen Terry, Volume 1 (1865-1888), ed. Katherine Cockin, London: Pickering and Chatto, pp. xiii-xxii

Cockin, Katharine, ed. (2014), The Collected Letters of Ellen Terry, Volume 5 (1905-1913), London: Pickering and Chatto.

Cockin, Katharine (2017), Edith Craig and the Theatres of Art, London: Bloomsbury.

Coward, Noël (2004), Present Indicative, London: Bloomsbury.

Davis, Tracy C. (1989), 'Questions for a Feminist Methodology in Theatre History', in Thomas Postlewait and Bruce McConachie, eds, Interpreting the Theatrical Past, Iowa City: University of Iowa Press, pp. 59-81.

Davis, Tracy C. (1991), Actresses as Working Women, London: Routledge.

Doan, Laura (2013), Disturbing Practices: History, Sexuality and Women's Experience of Modern War, Chicago: University of Chicago Press.

Dorney, Kate (2014a), 'Excavating Enthoven: Investigating a Life of Stuff', Studies in Theatre \& Performance, 32.2, pp. 115-25.

Dorney, Kate (2014b), 'Augusta Gabrielle Eden Enthoven', Oxford Dictionary of National Biography, Oxford: Oxford University Press, https://doi.org/10.1093/ ref:odnb/57054 (accessed 11 September 2018).

Enthoven, Gabrielle (1911a), letter to the Observer, 12 November, Enthoven scrapbook, V\&A, PN1620.L7.

Enthoven, Gabrielle (1911b), letter to the Referee, 12 November, Enthoven scrapbook, V\&A, PN1620.L7.

Fitzsimons, Eleanor (2015), Wilde's Women: How Oscar Wilde Was Shaped by the Women he Knew, London: Duckworth.

Fong, Bobby (1979), 'Oscar Wilde: Five Fugitive Pieces', English Literature in Transition, 1880-1920, 22.1, pp. 7-16.

Gale, Maggie B. (1996), West End Women: Women and the London Stage 19181962, London: Routledge.

Gere, Charlotte, and Marina Vaizey (1999), Great Women Collectors, London: Philip Wilson.

Harraden, Beatrice (2013), Lady Geraldine's Speech, in Naomi Paxton, ed., The Methuen Drama Book of Suffrage Plays, London: Bloomsbury.

Hindson, Catherine (2016), London's West End Actresses and the Origins of Celebrity Charity, 1880-1920, Iowa City: Iowa University Press. 
HMSO (1921), Notes from Reports by the Joint War Committee and the Joint War Finance Committee of the British Red Cross and the Order of St John of Jerusalem in England on Voluntary Aid rendered to the Sick and Wounded at Home and Abroad and to British Prisoners of War 1914-19 with Appendices, London: HMSO.

Holroyd, Michael (2004), 'Finding a Good Woman', in Mark Bostridge, ed., Lives for Sale: Biographers' Tales, London: Continuum.

Kennedy, Matthew (2004), Edmund Goulding's Dark Victory: Hollywood's Genius Bad Boy, Madison, WI: University of Wisconsin Press.

Kent, Christopher (1977), 'Image and Reality: The Actress and Society', in Martha Vicinus, ed., A Widening Sphere: Changing Roles of Victorian Women, London: Routledge, pp. 94-116.

Laver, James (1930), 'Sphere of Books', The Sphere, 12 April 1930, p. 82.

Laver, James (1952), 'Gabrielle Enthoven', in Studies in English Theatre History: In Memory of Gabrielle Enthoven, O.B.E., First President of the Society for Theatre Research, 1948-1950, London: Society for Theatre Research, pp. 1-9.

Lesley, Cole (1976), The Life of Noël Coward, London: Penguin.

Morley, Sheridan (1974), A Talent to Amuse: A Biography of Noël Coward, London: Penguin.

Nash, George (1956), 'Talk on the Gabrielle Enthoven Theatre Collection with introductory descriptive note about Mrs Enthoven for the Green Room Dramatic Club', unpublished typescript, V\&A Enthoven biographical file.

Parker, John, ed. (1930), Who's Who in the Theatre, London: Pitman.

Pilcher, Verlona (1929), The Searcher, London: Heinemann.

Price, Nancy (1953), Into an Hour-Glass, London: Museum Press.

Purkis, Charlotte (2016), 'The Mediation of Constructions of Pacifism in Journey's End and The Searcher, Two Contrasting Dramatic Memorials from the Late 1920s', Journalism Studies, 17.4, pp. 502-16.

Smith, Eve (2016), 'Private Passions, Public Archives: Approaches to the Private Collector and Collection of Theatrical Ephemera in the Context of the Public Theatre Archive', unpublished $\mathrm{PhD}$ thesis, University of London.

Souhami, Diana (2013), The Trials of Radclyffe Hall, London: Quercus.

Wark, Robert (1993), 'The Gentle Pastime of Extra-Illustrating Books', Huntington Library Quarterly, 56.2, pp. 151-65.

Williams, W. R. (2004), 'Romaine, William Govett (1815-1893)', rev. Lynn Milne, Oxford Dictionary of National Biography, Oxford: Oxford University Press, online edition.

\section{Archives}

\section{Victoria and Albert Museum}

Gabrielle Enthoven, unpublished typescript for Ellen Young, Personal Papers of Gabrielle Enthoven, V\&A, THM/114. 
Gabrielle Enthoven, letter to Constance Kyrle Fletcher, 22 May 1945, Gabrielle Enthoven Collection, V\&A, THM/114/6.

Gabrielle Enthoven, Last Will and Testament of Augusta Gabrielle Enthoven, 1951, Nominal File: Enthoven, Gabrielle, V\&A.

Guy Francis Laking, letters to Gabrielle Enthoven, Enthoven scrapbook, V\&A, PN1620.L7.

Farqharsson Sharp, letter to Gabrielle Enthoven, no date, Enthoven scrapbook, V\&A, PN1620.L7.

Cecil Harcourt Smith, letter to Gabrielle Enthoven, no date, Enthoven scrapbook, V\&A, PN1620.L7.

Christopher St John, letter to Gabrielle Enthoven, 10 July 1914, Gabrielle Enthoven Collection, V\&A, THM/114/6. 